\title{
Kesiapan Calon Guru SD dalam Implementasi Asesmen Nasional
}

\author{
Eka Nurjanah
}

Program Studi PGSD, Universitas PGRI Yogyakarta, Indonesia

${ }^{\bowtie}$ E-mail: nurjanahe865@gmail.com

\begin{abstract}
Abstrak
Penelitian ini bertujuan untuk mengetahui kesiapan calon guru SD terhadap implementasi Asesmen Nasional (AN) sebagai pengganti Ujian Nasional (AN). Pengetahuan tersebut meliputi sistem pelaksanaan AN, peserta AN khususnya di jenjang Sekolah Dasar, aspek-aspek yang dinilai dalam AN, dan persentase kesiapan calon guru SD sebagai pelaksana AN. Penelitian ini merupakan penelitian kuantitatif deskriptif dengan populasinya adalah calon guru SD pada Program Sarjana Pendidikan Guru Sekolah Dasar Universitas PGRI Yogyakarta tahun ajaran 2020/2021. Adapun jumlah sampelnya 50 calon guru SD semester 6. Instrumen yang digunakan berupa angket. Hasil penelitian menunjukkan bahwa pengetahuan calon guru SD khususnya semester enam belum memadai dimana hanya sekitar 33,3\% calon guru yang telah mengetahuinya secara tepat. Pengetahuan calon guru dalam implementasi AN diperoleh hanya $41,7 \%$ yang menjawab secara benar dan tepat. Adapun pengetahuan akan perlunya dilaksanakan AN diperoleh 29,2\% yang telah mengetahui secara tepat perlunya implementasi AN. Sedangkan untuk kesiapan calon guru SD sendiri dalam implementasi AN adalah $62,5 \%$ menyatakan siap. Simpulan penelitian ini adalah masih banyak calon guru SD yang belum mengetahui AN secara tepat dan calon guru SD yang masih belum siap dalam melaksanakan AN.
\end{abstract}

Kata Kunci: Pengetahuan; Kesiapan; Asesmen Nasional; Calon Guru SD

\begin{abstract}
This research aimed to know the knowledge and readiness of prospective elementary school teacher toward implementation of the National Assessment as a replacement for the National Examination. This knowledge includes the AN implementation system, AN participants especially at the elementary school level, the aspects assessed in AN, and the percentage of readiness of prospective elementary school teachers as AN implementers. This research is a descriptive quantitative research with the samples were 50 prospective elementary school teachers in the 6th semester. The instrument the form of a questionnaire. The results showed that the knowledge of prospective elementary school teachers, especially in the 6th semester, was not sufficient, where only $33.3 \%$ of prospective teachers knew it correctly. Knowledge of prospective teachers to parties or participants in the implementation of AN obtained only $41.7 \%$ who answered correctly and correctly. As for the knowledge of the need to implement AN, 29.2\% were found who knew exactly the need to implement AN. As for the readiness of prospective elementary school teachers themselves in the implementation of AN, $62.5 \%$ stated that they were ready. From theresult of this research, it can be concluded that there are still many prospective elementary school teachers.
\end{abstract}

Keywords: Knowledge; Readiness; National Assessment; Prospective Elementary School Teacher 


\section{PENDAHULUAN}

Pendidikan di Indonesia berpedoman pada kebudayaan bangsa dan berdasarkan pada Pancasila dan Undang-Undang Dasar Negara Republik Indonesia Tahun 1945. Undang-Undang Dasar Negara Republik Indonesia Tahun 1945 mengamanahkan upaya untuk mencerdaskan kehidupan bangsa yang bertujuan melaksanakan sistem nasional dan mewujudkan tujuan pendidikan nasional. Menurut Siti Mustaghfiroh (2020), pendidikan juga bertanggung jawab membina peserta didik agar dewasa, berani, mandiri, dan berusaha sendiri, sehingga nuansa pendidikan semestinya diupayakan agar memberikan kesempatan kepada peserta didik untuk selalu berfikir mandiri dan kritis dalam menemukan jati dirinya. Dalam hal ini, yang terpenting bukanlah memberikan pengetahuan positif yang bersifat taken for granted kepada peserta didik, melainkan bagaimana mengajarkan kepada peserta didik agar memiliki kekuatan bernalar. Salah satu upaya yang dapat dilakukan adalah dengan memberikan kemerdekaan peserta didik untuk terlibat langsung dalam proses pembelajaran dan transfer keilmuan. Dalam hal ini, peserta didik seharusnya berperan sebagai subjek atau pemeran utama bukan hanya sekedar objek dari sebuah proses pendidikan. Pembangunan pendidikan suatu bangsa tidak akan pernah usai dan selesai, oleh karena itu pengendalian mutu sangat diperlukan. Hal ini diperlukan agar di masa depan sistem pendidikan lebih terarah, efisien, efektif, relevan dan berkembang sesuai dengan dinamika kehidupan masyarakat suatu bangsa. Salah satu upaya yang dilakukan pemerintah untuk mengendalikan mutu pendidikan adalah dengan melaksanakan evaluasi.

Evaluasi mengacu pada proses pengumpulan data secara berkala dan kemudian di analisis sehingga informasi yang dihasilkan dapat digunakan untuk menentukan keefektifan pengajaran yang dilaksanakan, dan sejauh mana dapat mencapai tujuan utama program pendidikan dan hasil yang diharapkan. Evaluasi dilakukan oleh lembaga yang mandiri secara berkala, menyeluruh, transparan, dan sistematis untuk menilai pencapaian standar nasional pendidikan. sistem evaluasi di Indonesia telah diatur dalam Undang-Undang Republik Indonesia Nomor 20 Tahun 2003 Bab XVI tentang sistem pendidikan Nasional pasal 57 ayat 1 menyebutkan bahwa "Evaluasi dilakukan dalam rangka pengendalian mutu pendidikan secara nasional sebagai bentuk akuntabilitas penyelenggara pendidikan kepada pihakpihak yang berkepentingan”. Kemudian dalam pasal 59 ayat 1 menyatakan bahwa "Pemerintah dan Pemerintah Daerah melakukan evaluasi terhadap pengelola, satuan, jalur, jenjang, dan jenis pendidikan. Oleh karena itu, hendaklah setiap langkah evaluasi didasarkan pada prinsip untuk mencapai sesuatu yang lebih baik dari sebelumnya, dengan demikian, setiap evaluasi adalah upaya untuk mencapai kualitas penidikan yang lebih baik.

Hingga tahun 2019, pemerintah melakukan penilaian pendidikan secara nasional melalui Ujian Nasional (UN) di akhir jenjang. Dengan mengandalkan UN sebagai satu-satunya komponen penilai keberhasilan siswa tentu salah besar. UN hanya mengukur pengetahuan siswa tanpa ada penilaian aspek sikap dan psikomotorik siswa. Selain itu, Indonesia konsisten sebagai salah satu negara dengan peringkat PISA terendah. Indonesia mendapat skor PISA yang stagnan dalam 10-15 tahun terakhir. Berdasarkan laporan PISA, skor membaca Indonesia ada di peringkat 72 dari 77 negara, 
lalu skor matematika ada di peringkat 72 dari 78 negara, dan skor sains ada di peringkat 70 dari 78 negara. Ini membuktikan bahwasannya implementasi kebijakan Ujian Nasional dinilai gagal setelah berlangsung lebih dari 10 tahun lamanya.

Dinamika perkembangan pendidikan nasional di Republik Indonesia selalu mengalami pergantian kebijakan. Kebijakan terganti karena setiap pergantian stakeholder yang selalu memiliki desain baru untuk model pendidikan nasional. Indonesia setidaknya telah mengalami lebih dari sepuluh kali perubahan dalam pengembangan kurikulum sejak awal kemerdekaan. Mulai dari Rentjana Pembelajaran 1947 hingga Merdeka Belajar yang digaungkan pada tahun 2020. Merdeka Belajar yang digaungkan oleh Kementerian Pendidikan dan Kebudayaan di bawah naungan Nadiem Makarim menambahkan fakta bahwa dalam kurun waktu kurang dari 10 tahun saja, Indonesia telah melakukan pergantian kurikulum sebanyak 3 kali. Hal tersebut tak lain yaitu untuk menjawab kebutuhan Indonesia yang berubah sesuai kemajuan zaman, baik secara intern maupun ekstern. Dengan demikian, Indonesia diharapkan dapat mempersiapkan perserta didik agar bisa bersaing di masa yang mendatang. Menteri Pendidikan dan Kebudayaan Republik Indonesia, Nadiem Makarim menyatakan bahwa evaluasi pendidikan yang sebelumnya menggunakan Ujian Nasional akan di ubah formatnya menjadi asesmen kompetensi. Asesmen kompetensi yang dimaksud adalah asesmen nasional yang merupakan pemetaan mutu pendidikan pada seluruh sekolah, madrasah, dan program kesetaran jenjang dasar dan menengah. Asesemen nasional dilakukan untuk mengevaluasi kinerja satuan pendidikan dan sekaligus menghasilkan informasi untuk perbaikan kualitas belajar mengajar, yang kemudian diharapkan berdampak pada karakter dan kompetensi siswa. Menurut Nadiem Makarim, asesmen kompetensi yang digaungkan melalui Kebijakan Merdeka Belajar merupakan hasil audiensi dan kesepakatan dari berbagai seluruh pihak terkait seperti siswa, wali murid, guru dan stakeholder lainya dalam ranah pendidikan, asesmen kompetensi ini disusun agar guru dapat secara mandiri melaksanakan terhadap siswanya (Kemendikbud RI, 2019). Rencana perubahan kebijkan ini dapat menimbulkan tantangan baru bagi seluruh pihak yang terkait, baik siswa, guru, maupun pihak lainya. Pelaksanaan Ujian Nasional yang awalnya berbasis sumatif dan kognitif akan berubah drastis menjadi penilaian yang berbasis formatif, aplikasi dan analisis.

Asesmen merupakan bagian integral dari proses pendidikan. Fungsi asesmen dalam pendidikan yaitu sebagai peneyedia informasi untuk: (1) perbaikan pendididkan, (2) pengendalian mutu pendidikan, efektivitas pendidian, (4) seleksi, penentuan tingkat keberhnasilan dan (6) akuntabilitas publik.

Asesmen Nasional sebagai pengganti Ujian Nasional memiliki tujuan untuk menghasilkan informasi mengenai peserta didik, kemudian informasi peserta didik tersebut digunakan olrh pendidik untuk meningkakan kualitas kegiatan belajar mengajar. Asesmen Nasional terdiri dari tiga bagian, yaitu Asesmen Kompetensi Minimum (AKM), Surveri Karakter, dan Survei Lingkungan belajar. AKM dirancang untuk mengukur capaian peserta didik dari belajar kognitif, yaitu literasi dan numerasi. Kemampuan literasi dan numerisasi ini menjadi syarat bagi peserta didik untuk berkontribusi di dalam masyarakat, terlepas dari bidang kerja dan karier yang ingin 
mereka tekuni di masa depan. Hal ini dikaitkan dengan tuntutan kecakapan abad 21, dimana literasi menjadi salah satu kompetensi yang harus dikuasai pesereta didik agar mampu bersaing dengan dunia luar di era revolusi industri 4.0. Kemudian survei karakter dirancang untuk mengukur capaian peserta didik dari hasil belajar sosialemosional berupa pilar karakter untuk mencetak profil pelajar Pancasila. Survei karakter akan menjadi tolak ukur untuk bisa memberikan umpan balik atau feedback ke sekolah-sekolah agar dapat menciptakan lingkungan sekolah yang membuat siswa lebih memahami dan menerapkan asas Pancasila. Yang terakhir adalah survei lingkungan belajar yang berfungsi untuk mengevaluasi dan memetakan aspek pendukung kualitas pembelajaran di lingkungan sekolah. Adapun peserta ataupun pihak yang terlibat dalam Asesmen Nasional adalah kepala satuan pendidikan (kepsek), seluruh guru/pendidik, peserta didik (kelas 5 untuk jenjang Sekolah Dasar). Alasan mengapa pelaksanaannya dilakukan di tengah jenjang pendidikan telah disampaikan oleh

Mendikbud, yaitu (1) pelaksanaan AN dilakukan di tengah jenjang akan bisa memberikan waktu untuk sekolah dan guru dalam melakukan perbaikan sebelum peserta didik lulus pada jenjang itu, (2) AN dilaksanakan di tengah jenjang, tidak akan menimbulkan stres pada peserta didik dan orang tua karena AN tidak bisa digunakan sebagai alat seleksi peserta didik. Secara umum, ada karakteristik tertentu yang menjadikan AKM, survei karakter, dan lingkungan belajar ini menjadikan satu keniscahyaan dengan harapan besar untuk bias membawa pendidikan di Indonesia untuk lebih maju. Salah satu indikatornya adalah perbaikan peringkat peserta didik untuk dapat bersaing dalam menghadapi soal-soal yang membutuhkan high order thingking skill (HOTS) yang merupakan ciri khas dari PISA.

Menteri Nadiem Makarim memaparkan, ada beberapa alasan yang melatarbelakangi diundurnya pelaksanaan Asesmen Nasional. Salah satunya jumlah kasus Covid-19 yang terus meningkat. Alasan lain pelaksanaan Asesmen Nasional ditunda adalah untuk memastikan kesiapan sekolah penyelenggara Asesmen Nasional memiliki sarana dan prasarana protokol kesehatan yang memadai. Begitu juga untuk urusan logistik pelaksanaan Asesmen Nasional. Sebelum benar-benar dilaksanakan Asesmen Nasional, perlu adanya edukasi tentang hal ini untuk para calon guru terutama guru SD yang mana menjadi pondasi pendidikan siswa. Ditjen P3GTK Kementrian Pendidikan dan Kebudayaaan telah memulai persiapan Asesmen Nasional pada tahun 2020. Pemerintah melakukan uji coba Survey Karakter dan Lingkungan Belajar untuk mengembangkan instrument ysng valid dan reliabel pada tanggal 12 Juni 2020 sampai dengan tanggal 24 Juni 2020. Uji coba instrumen Survey Karakter dan Lingkungan Belajar dilakukan pada 22 sekolah dari perwakilan Provinsi Aceh, DKI Jakarta, Nusa Tenggara Timur, Sulawesi Selatan, Papua, dan Papua Barat. Dalam realitanya, para calon guru SD (mahasiswa) belum memahami teknis pelaksanaan, tujuan, dan manfaat Asesmen Nasional ini. Seorang pendidik memiliki peran penting dalam proses penilaian peserta didik sesuai dengan Peraturan Menteri Pendidikan No. 104 Tahun 2014 Pasal 1 Tentang Hasil Belajar yang menjelaskan bahwa "Penilaian hasil belajar oleh pendidik adalah proses pengumpulan informasi/bukti tentang capaian pembelajaran peserta didik dalam kompetensi sikap 
spiritual dan sikap sosial, kompetensi pengetahuan, dan kompetensi keterampilan yang dilakukan secara terencana dan sistematis, selama dan setelah proses pembelajaran". Para calon guru SD seharusnya memahami arah pendidikan yang akan dibawa oleh Mendikbud saat ini. Menurut Nadiem Makarim, esensi kemerdekaan berpikir harus didahului oleh para guru sebelum mereka mengajarkanya pada peserta didik. Terlepas kompetensi guru yang sangat beragam, tanpa ada proses implementasi dari kompetensi dasar dan kurikulum yang ada, maka tidak akan pernah ada pembelajaran yang terjadi. Berangkat dari hal tersebut maka peneliti ingin melakukan penelitian dengan judul "Kesiapan Calon Guru SD dalam Implementasi Asesmen Nasional" yang dilakukan untuk mengetahui sejauh mana kesiapan calon guru SD dalam mengahadapi Asesmen Nasional meliputi sistem pelaksanaan AN, peserta yang ikut AN, aspek-aspek yang di nilai dalam AN, serta komponen apa saja yang di ukur dalam pelaksanaan AN. Sebagai calon guru yang nantinya berperan dalam dunia pendidikan wajib melek informasi dan cepat tanggap terutama yang terkait dengan perubahan kebijakan-kebijakan dalam sistem pendidikan.

\section{METODE PENELITIAN}

Penelitian ini menggunakan metode survei dengan jenis penelitian kuantitatif deskriptif. Adapun instrumen yang digunakan untuk mengumpulkan data adalah angket menggunakan google form. Link google form diberikan kepada seluruh calon guru program studi Pendidikan Guru Sekolah Dasar Universitas PGRI Yogyakarta. Populasi dari penelitian ini adalah seluruh calon guru sekolah dasar Universitas PGRI
Yogyakarta tahun ajaran 2020/2021 pada program studi Pendidikan Guru Sekolah Dasar semester VI berjumlah sekitar 200 calon guru sekolah dasar. Jumlah sampel yang digunakan adalah 50 calon guru sesuai dengan penentuan jumlah sampel dengan tingkat kesalahan 5\% yang dikembangkan dari Isaac dan Michael dalam Sugiyono (2019). Prosedur dalam penelitian ini sebagai berikut (1) Merancang instrumen penelitian berupa angket terkait pengetahuan dan kesiapan calon guru terhadap implementasi asesmen nasional di SD (2) Validasi angket oleh rekan sejawat (3) Melakukan revisi instrumen (4) Penentuan sampel berdasarkan populasi (5) Melakukan pengambilan data (6) melakukan analisis data secara deskriptif. Pengumpulan data penelitian menggunakan instrumen berupa angket tentang pengetahuan dan kesiapan calon guru terhadap implementasi asesmen nasional di SD yaitu (1) Pengetahuan aspek yang dinilai dari AN sebagai pengganti Ujian Nasional (UN) (2) Pihak yang terlibat/mengikuti AN (3) Alasan perlu diadakan AN (4) Kesiapan calon guru sebagai calon pelaksana AN di SD. Setiap jawaban dari soal angket memiliki nilai, dengan skor 4 (tingkat kebenaran 100\%), 3 (tingkat kebenaran 75\%), 2 (tingkat kebenaran 50\%), 1 (tingkat kebenaran 25\%).

\section{HASIL DAN PEMBAHASAN}

Asesmen Nasional (AN) merupakan program pemerintah untuk menilai kualitas (mutu) setiap lembaga pendidikan formal setara SD, SMP dan SMA. Dalam hal ini yang dibahas khusus dalam jenjang sekolah dasar. Kualitas dinilai dari hasil belajar peserta didik yang paling dasar. Untuk klasifikasi tersebut digunakan instrumen yaitu asesmen kompetensi minimum, survei karakter dan survei lingkungan belajar. AN 
dirancang untuk memperbaiki kualitas dalam hal pembelajaran dengan tujuan meningkatkan hasil belajar peserta didik dan menghasilkan informasi yang akurat. Deskripsi pengetahuan calon guru terhadap aspek yang dinilai dalam asesmen nasional sebagai pengganti ujian nasional. Pertanyaan pertama, Ujian Nasional (UN) merupakan sistem evaluasi ketercapaian standar pendidikan secara nasional. Pada akhir tahun 2019, UN resmi dihapuskan dan pada tahun 2021 UN diganti dengan AN. Menurut pengetahuan Anda, apa saja yang diukur dalam asesmen nasional? Persentase jawaban calon guru ditunjukkan pada Gambar 1.
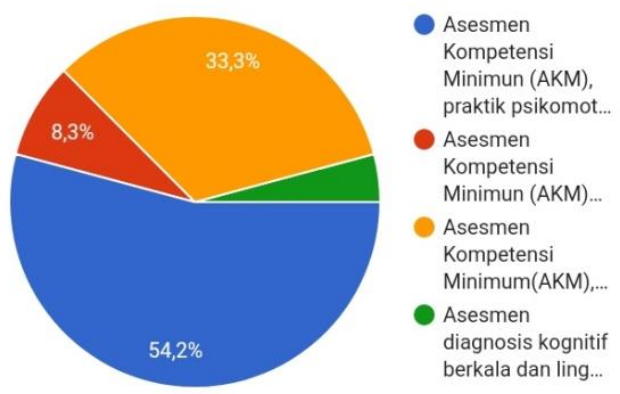

Gambar 1. Pengetahuan aspek yang dinilai dari AN sebagai pengganti UN

Berdasarkan Gambar 1 diketahui bahwa 33,3\% calon guru mendapat skor 4 artinya menjawab dengan benar seluruh aspek yang jadi penilaian pada AN yaitu Asesmen Kompetensi Minimum (AKM), lingkungan belajar, dan survei karakter, 8,3 $\%$ jawaban calon guru mendapat skor 3 artinya jawaban calon guru belum sepenuhnya benar, jawaban yang dipilih calon guru yaitu Asesmen Kompetensi Minumum (AKM) dan survei karakter jawaban ini tidak lengkap karena masih ada aspek lingkungan belajar merupakan aspek lainnya dalam penilaian AN. Skor 2 sejumlah $54,2 \%$ dari calon guru menjawab Asesmen Kompetensi Minimum (AKM), praktik psikomotorik, dan survei karakter, dari pilihan tersebut praktik psikomotorik bukan aspek yang menjadi penilaian dalam AN. skor 1 sejumlah 4,2 \% calon guru memilih jawaban asesmen diagnosis kognitif berkala dan lingkungan belajar, ini bukan merupakan aspek yang menjadi penilaian AN. Dari data tersebut dapat diasumsikan bahwa kdari setengah sampel belum mengetahui dengan benar aspek yang menjadi penilaian dari AN.

Untuk memetakan dan mengetahui potret layanan dan kinerja sekolah diperlukan keterlibatan pihak-pihak yang membantu program ini khususnya pada jenjang SD. Calon guru seharusnya mengetahui pihak yang terlibat dalam AN. Dari analisa angket pengetahuan calon guru terhadap pertanyaan siapa saja yang harus mengikuti AN, jawaban calon guru hanya $41,7 \%$ yang memperoleh skor 4 artinya calon guru dapat menjawab dengan benar bahwa yang mengikuti AN yaitu kepala sekolah, seluruh guru, dan siswa terpilih dari kelas $\mathrm{V}$ berdasarkan stratifikasi sosial ekonomi, calon guru menjawab 8,3\% dari pertanyaan tersebut dengan jawaban bahwa yang mengikuti AN adalah sebagian siswa terpilih dari kelas V, kepala sekolah dan sebagian guru, jawaban tersebut kurang tepat dikarenakan seluruh guru terlibat dalam AN. Sekitar 33,3\% calon guru memperoleh skor 2 dengan menjawab kepala sekolah, sebagian guru, dan sebagian siswa kelas VI, disini sebagian guru dan sebagian siswa kelas VI adalah jawaban yang keliru, karena yang terlibat adalah sebagian siswa dari kelas tertentu (bukan kelas pada tingkatan akhir) dan berdasarkan kriteria tertentu, sebagian besar calon guru memperoleh skor 1 yang merupakan skor minimum yaitu $16,7 \%$ calon guru beranggapan bahwa yang mengikuti AN adalah sebagian siswa kelas VI dan semua guru, dari hasil analisa ini dapat diasumsikan pengetahuan calon guru tentang pihak yang akan mengikuti AN masih keliru, mereka masih beranggapan AN sama halnya dengan 
UN yang diuji kepada siswa yang menempati kelas akhir. Dalam pelaksanaan AN, asesmen ini diikuti oleh seluruh satuan pendidikan tingkat dasar di Indonesia juga satuan pendidikan kesetaraan. Untuk peserta didik AN diikuti oleh peseta didik tingkat dasar kelas V. Akan tetapi, untuk pendidikan kesetaraan, peserta AN adalah peserta didik yang pada akhir jenjang, yaitu untuk paket $\mathrm{A}$ kelas VI yang sudah memenuhi kriteria peserta AN. Selain siswa, AN juga akan diikuti oleh guru dan kepala sekolah di setiap satuan pendidikan. Informasi dari peserta didik, guru, dan kepala sekolah berguna untuk memberikan informasi yang lengkap tentang kualitas proses dan hasil belajar di setiap satuan pendidikan sehingga perbaikan bisa dilakukan. Hal ini bisa dilihat pada gambar 2.

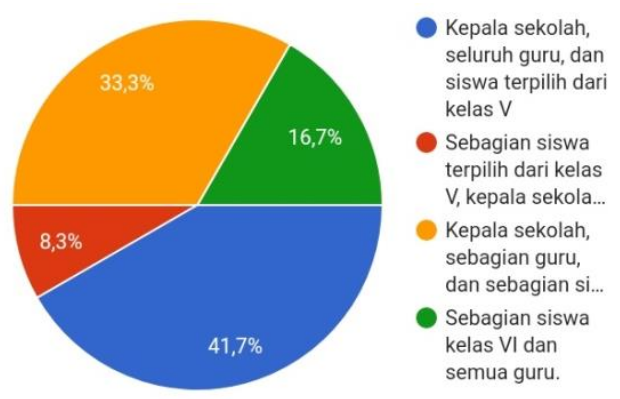

Gambar 2. Pengetahuan calon guru terhadap pihak dan peserta yang terlibat dalam AN

Pada soal angket bagian ketiga, aspek yang ingin diketahui adalah pengetahuan calon guru serta alasan perlunya AN. Dari AN dapat menunjukkan tujuan dari pendidikan secara nasional antara lain mengembangkan potensi dan karakter setiap peserta didik. Serta melakukan evaluasi terhadap sekolah dan membantu untuk mewujudkan pemerataan pendidikan diseluruh Indonesia.

Selanjutnya, persentase calon guru yang memberikan alasan dengan benar sesuai dengan tujuan yang ditetapkan pemerintah bahwa perlunya AN. Telah dilakukan survey sehingga memperoleh data seperti gambar 3 .
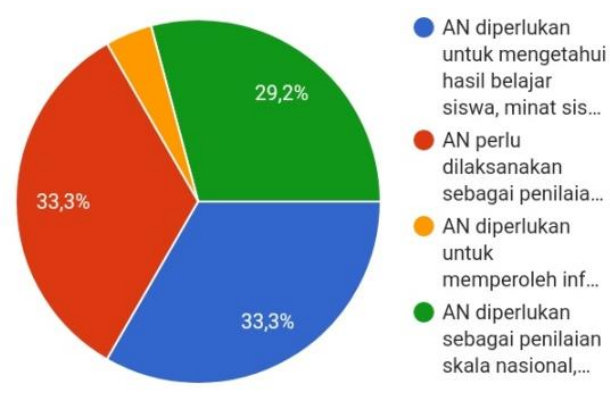

Gambar 3. Pengetahuan calon guru terhadap perlunya AN

Data pada gambar 3. Menunjukkan bahwa sejumlah 29,2\% calon guru menjawab dengan alasan yang paling sesuai dan memperoleh skor 4, bahwa perlunya $\mathrm{AN}$ yaitu sebagai penilaian skala nasional, memperoleh informasi pemetaan dalam pendidikan, mengukur kualitas pembelajaran, dan mengetahui hasil belajar siswa. Calon guru memperoleh skor 3 dengan persentase $4,2 \%$ calon guru memilih jawaban AN diperlukan untuk memperoleh informasi pemetaan dalam pendidikan, mengukur kualitas pembelajaran, mengetahui hasil belajar siswa, dan minat siswa. Persentase calon guru memperoleh skor 2 yaitu 33.3\%, sebagian kecil dari calon guru memberi alasan bahwa AN perlu dilaksanakan sebagai penilaian skala nasional, memperoleh informasi pemetaan dalam pendidikan, mengukur minat siswa, dan menilai kinerja pimpinan sekolah dan 33,3\% dari total sampel memberi alasan bahwa AN diperlukan untuk mengetahui hasil belajar siswa, minat siswa, kinerja pimpinan sekolah dan mengukur kinerja guru.

Aspek keempat menilai calon guru terhadap kesiapan calon guru SD terhadap implementasi AN. Dalam aspek ini dapat dilihat berapa rata-rata presentase kesiapan calon guru. Presentase jawaban calon guru ditunjukkan pada diagram batang pada 
gambar 4.

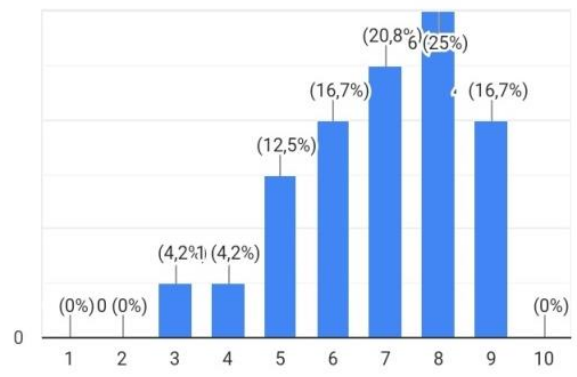

Gambar 4. Kesiapan calon guru terhadap implementasi AN

Berdasarkan Gambar 4, sebesar 62,5\% dari responden menyatakan siap dalam mengimplementasikan AN sebagai sistem evaluasi nasional dalam pendidikan, sedangkan $37,5 \%$ menyatakan kurang siap dalam implementasi AN dan sisanya masih belum siap.

\section{KESIMPULAN}

Asesmen Nasional (AN) merupakan program pengganti Ujian Nasional (UN) adalah program penilaian terhadap mutu setiap satuan pendidikan yang di nilai berdasarkan hasil belajar peserta didik yang mendasar (literasi, numerasi, dan karakter) serta kualitas proses belajar-mengajar dan iklim satuan pendidikan yang mendukung pembelajaran. Sampai saat ini, implementasi kebijakan Asesmen Nasional nelum bisa diukur keberhasilannya, karena kegiatannya itu sendir belum terlaksana mengingat keadaan pandermi Covid-19. Hanya dalam batas-batas sosialisasi program Asesmen Nasionl, tampaknya Kemendikbud sudah berhasil mengomunikasikan maksud dan tujuan AN. Akan tetapi, sosialisasi tersebut belum sepenuhnya tersampaikan pada calon guru khususnya mahasiswa jurusan PGSD. Menurut hasil penelitian di atas, pengetahuan calon guru terhadap aspek yang dinilai dari AN sebagai pengganti UN menunjukkan $33,3 \%$ calon guru sudah mengetahui dengan benar aspek yang menjadi penilaian dari AN.
Pengetahuan calon guru terhadap pihak yang terlibat dalam AN diperoleh hanya 41,7\% yang mengetahui secara benar dan tepat. Untuk pengetahuan selanjutnya yang diukur adalah pengetahuan calon guru terhadap perlunya AN dilaksanakan dan diperoleh $29,2 \%$ calon guru sudah mengetahui dengan tepat perlunya pelaksanaan AN. Untuk kesiapan calon guru terhadap implementasi AN sebesar 62,5\% menyatakan siap untuk melaksanakannya. Secara keseluruhan dapat disimpukan pengetahuan calon guru terhadap sistem pelaksanaan AN masih belum memadai. Sedangkan kesiapan dari calon guru terhadap implementasi AN sebagai sistem evaluasi nasional dalam pendidikan dinilai cukup. Namun kesiapan calon guru tidak memadai jika tidak disertai pengetahuan tentang AN dengan benar.

Calon guru wajib melek informasi, kreatif, produktif dan memahami perannya sebagai calon pendidik terkait dunia pendidikan terutama terhadap perubahan kebijakan dalam pelaksanaan sistem pendidikan. Seperti perubahan sistem evaluasi pendidikan dari UN berubah menjadi AN, dengan tujuan untuk meningkatkan mutu pendidikan Indonesia. Selain itu peran pemerintah dalam mendukung kesiapan para guru dan calon guru dalam menghadapi setiap perubahan sistem pendidikan sangat diperlukan. Dukungan dapat dilakukan baik dengan memberikan informasi yang jelas dan akurat, serta mengadakan pelatihan-pelatihan terstruktur kepada pihak-pihak yang terlibat seperti kepala sekolah, guru, serta peserta didik.

\section{DAFTAR RUJUKAN}

Albertus Adit. 2019. UN Tidak Dihapuskan Tapi Sistemnya Diganti, Ini Pernyataan Nadiem Terbaru. Kompas, 13 Desember 2019. 
Anas, M, dkk. 2021. Pengembangan Kemampuan Guru Ekonomi di Kediri melalui Kegiatan Pelatihan Asesmen Kompetensi Minimum (AKM). Universitan Nusantara PGRI Kediri. Renggnanis Jurnal Pengabdian Masyarakat 1 (1), 48-5 7. Diakses dari: https://mathjournal.unram.ac.id/index.p $\mathrm{hp} /$ Renggans/index

Andriani, Juli dkk. 2018. Analisis Kesiapan Guru Kelas dalam Implementasi Penilaian Otentik Pada Kompetensi Ranah Sikap di SD Negeri Kecamatan Tebing Tinggi Kota. Universitas Negeri Medan hal 172-182. Diakses dari: https://jurnal.unimed.ac.id/2012/index. $\mathrm{php/tematik/rticle/view/12566}$

Aisah, Heti, dkk. 2021. Implementasi Kebijakan Asesmeen Kemampuan Minimum (AKM): Analisis Implementasi Kebijakan AKM. 1 (2), 128-135. Diakses dari: http://ejournal.stitalquraniyah.ac.id/index.php/jpia/

Ayunda Pininta Kasih. 2020. Tahun Depan UN Diganti Asesmen Nasional, Ini Penjelasan Mendikbud. Kompas, 7 Oktober 2020.

Dikdasmen Kemendikbud. 2020. Sosialisasi Asesmen Nasional. Bidang Penilaian Direktorat SMA Dirjen PAUD.

Khasanah, E. R. 2015. Pelaksanaan Penilaian Autentik pada Kurikulum 2013 di SD Kota Mojokerto. Universitas Negeri Malang. Diakses dari:

https://library.um.ac.id/ptk/index.php $\bmod =$ detail $\&$ id $=69263$

Kemendikbud. 2020. Penyelenggaraan Asesmen Nasional Tahun 2021. Jakarta: Balitbang dan Perbukuan.

Kurnia, Tommy. 2019. Skor Terbaru PISA: Indonesia Merosot di Bidang Membaca, Sains, dan Matematika. Liputan 6, 4 Desember 2019.

Mustaghfiroh, Siti. 2020. Konsep "Merdeka Belajar" Perspektif Aliran Progresivisme John Dewey. 3 (1), 141147. http://doi.org/10.30 605/jsgp. 3. 1.2020 .248
Muta'ali, Jihad Ahmad. Opini Masyarakat tentang Asesmen Nasional sebagai Pengganti Ujian Nasional. Jakarta: Universitas Pendidikan Indonesia. Diakses dari:https://www.academia.edu/442960 48/OPINI_MASYARAKAT_TENTA NG_ASESMEN_NASIONAL_SEBA GAI_PENGANTI_UJIAN_NASIONA L_Studi_kasus_terhadap_Masyarakat_ Awam_dan_Masyarakat_Intelektual

Nehru, Nio Awandha. Asesmen Kompetensi sebagai Bentuk Perubahan Ujian Nasional Pendidikan Indonesia: Analisis Dampak dan Problem-Solving Menurut Kebijakan Merdeka Belajar. Universitas Islam Balitar Blitar. Diakses dari: https://www.academia.edu/42222001/A SESMEN_KOMPETENSI_SEBAGAI _BENTUK_PERUBAHAN_UJIAN_N ASIONAL_PENDIDIKAN_INDONES IA_ANALISIS_DAMPAK_DAN_PR OBLEM_SOLVING_MENURUT_KE BIJAKAN_MERDEKA_BELAJAR

Novita, Nanda. dkk. 2020. Asesmen Nasional (AN): Pengetahuan dan Persepsi Calon Guru. 5 (1), 172-179. Diakses dari: http://ejournal.mandalanursa.org/index. php/JISIP/index

Peraturan Menteri Pendidikan No. 104 Tahun 2014 Pasal 1 Tentang Hasil Belajar

PUSMENJAR KEMENDIKBUD. 2021. Mekanisme Pelaksanaan Asesmen Nasional Tahun 2021. Disampaikan pada Rapat Koordinasi Persiapan Asesmen Nasional Tahun 2021 di Bandung, 2-27 Februari 2021.

Rokhim, Deni Ainur, dkk. 2021. Analisis Kesiapan Peserta didik dan Guru pada Asesmen Nasional (Asesmen Kompetensi Minimum, Survei Karakter, dan Survei Lingkungan Belajar). 4 (1), 61-71. Diakses dari: http://jornal2.um.ac.id/index.php/jamp/ Sari, Ayang, dkk. 2020. Penghapusan Ujian Nasional Tahun 2021 dalam Perspektif Guru SMA di Kota Tefbing Tingi. Prosiding Seminar Nasional PBSI-III 
Tahun 2020 hal 213-219. Diakses dari: http://digilib.unimed.ac.id/41244/1/Full text.pdf

Sugiri, Wiku Aji dan Sigit Priatmiko. 2020. Perspekif Asesmen Autentik sebagai Alat Evaluasi dalam Merdeka Belajar. 4 (1), 53-61. P-ISSN: 2579-625. Diakses dari: https://journalfai.unisla.ac.id/index.php /at-thulab/article/view/119

Sugiyono. 2019. Metode Penelitian Kuantitatif, Kualitatif, dan $R \& D$.
Alfabeta.

Yuliatri, Rury. 2020. Berikut 3 Aspek Penilaian Asesmen Nasional Pengganti UN 2021. Disdik Jabar, 12 Oktober 2020.

Undang-Undang Dasar Negara Republik Indonesia Tahun 1945.

Undang-Undang Republik Indonesia Nomor 20 Tahun 2003 Bab XVI tentang sistem pendidikan Nasional pasal 51 dan 59.

Yusuf. A. Muri. 2015. Asesmen dan Evaluasi Pendidikan. Jakarta: Kencana 